\title{
NEW VELOCITY ANALYSIS IN GEODYNAMIC NETWORK SNĚŽNÍK BASED ON GNSS MEASUREMENT REPROCESSING USING REPROCESSED IGS PRODUCTS
}

\author{
Lukáš PUCHRIK *, Otakar ŠVÁBENSKÝ, Lubomil POSPÍŠIL and Josef WEIGEL
}

Institute of Geodesy, Brno University of Technology, Veveři 331/95, 60200 Brno, Czech Republic

*Corresponding author's e-mail: puchrik.1@fce.vutbr.cz

\begin{tabular}{l} 
ARTICLE INFO \\
\hline Article history: \\
Received 6 February 2013 \\
Accepted 13 June 2013 \\
Available online 26 November 2013 \\
\hline
\end{tabular}

\section{Keywords:}

Geodynamics

GNSS

IGS reprocessing

Precise point positioning

Recent movement tendencies

Sněžník metamorphic unit

\begin{abstract}
Since 2006 the International GNSS Service (IGS) started with reprocessing of all IGS products (Steigenberger et al., 2006; Ferland, 2010) according newly adopted models and reference frame. The resulting reprocessed products are of superior quality and homogeneous through the whole time span. Moreover the IGS re-processing made available all the products also for the period before year 2000 when IGS originally started to provide them. The availability of those products was the main motivation for a comprehensive reprocessing of all GNSS data from the Local Geodynamic Sněžník Network from the period between 1997 and 2011. All calculations were performed in the Bernese GPS software 5.0. The absolute method of Precise Point Positioning (PPP) was used for the first time within the network providing interesting results. The main evaluation of recent movement tendencies was done using common relative method where the nearest IGS points were used as reference points.
\end{abstract}

\section{INTRODUCTION}

The history of research activities in the area of Králický Sněžník massif (Fig. 1) started in early 1990s. As a breakthrough can be considered the establishment of Local Geodynamic Sněžník Network (LGSN) which was build up in cooperation of Institute of Geodesy and Geoinformatics, Wrocław University of Environmental and Life Sciences (former Department of Geodesy and Photogrammetry AU Wroclaw) and Institute of Geodesy, Brno University of Technology (BUT) in 1992. Detailed description of LGSN provides (Cacoń et al., 1996; Švábenský and Weigel, 1999; Cacoń et al., 2004). The main purpose of the network is the monitoring of upper lithosphere movement but it serves also for other research activities in field of geodetic astronomy, gravimetry and others (Cacoń et al., 2004). Detailed description of geological characteristics of the Králický Sněžník massif and surrounding areas is presented in (Gawlikowska and Opletal, 1997; Birkenmayer et al., 2002). Essential activities in the network are related to the GNSS measurements which are being realized in epoch-wise manner. Partial results of research activities in LGSN have been presented by many authors since the establishment of the network (Švábenský and Weigel, 2007; Jamroz, 2008; Cacoń et al., 2004, Švábenský et al., 2012). This article deals with comprehensive reprocessing of all GNSS data measured in Czech part of LGSN between years 1997 and 2011 and will refer to previously presented results from (Švábenský and Weigel, 2007; Švábenský et al., 2012) The main motivation for a complete reprocessing are the results of the first IGS reprocessing campaign (Steigenberger et al., 2006; Ferland, 2010) which are being used for the first time within the LGSN. The reprocessed IGS products are not only of better quality but their quality is also homogenous through the whole processed time span (Meindl et al., 2012). More over the campaign of the first reprocessing had made available the IGS final products also for the period before year 2000 when IGS originally started to provide its products.

\section{GNSS MEASUREMENT}

The network was firstly observed using GNSS in 1992 but only since 1997 the observations are longer than 24 hours and therefore reliable for positional monitoring. The annual campaign is realized each year in May during the field practices of the BUT students. Most of LGSN points are located far from any infrastructure so there is no possibility to observe them permanently and due to this fact, all of the GNSS measurements from LGSN are epoch-wise. During the whole time span between 1997 and 2011, 12 different types of GNSS antennas were used. Since the 2005 started the unification of the used instrumentation, as well as its planned distribution on the points (same antenna on same point in different epoch). An overview of observation duration and number of used antenna types is listed in Table 1.

To be able to distinguish any geodynamic movements is absolutely crucial to eliminate all of systematic effects because unlike for evaluation of permanently observed networks the possibility of sophisticated filtering is for epoch-wise measured networks very limited. Therefore the comprehensive 


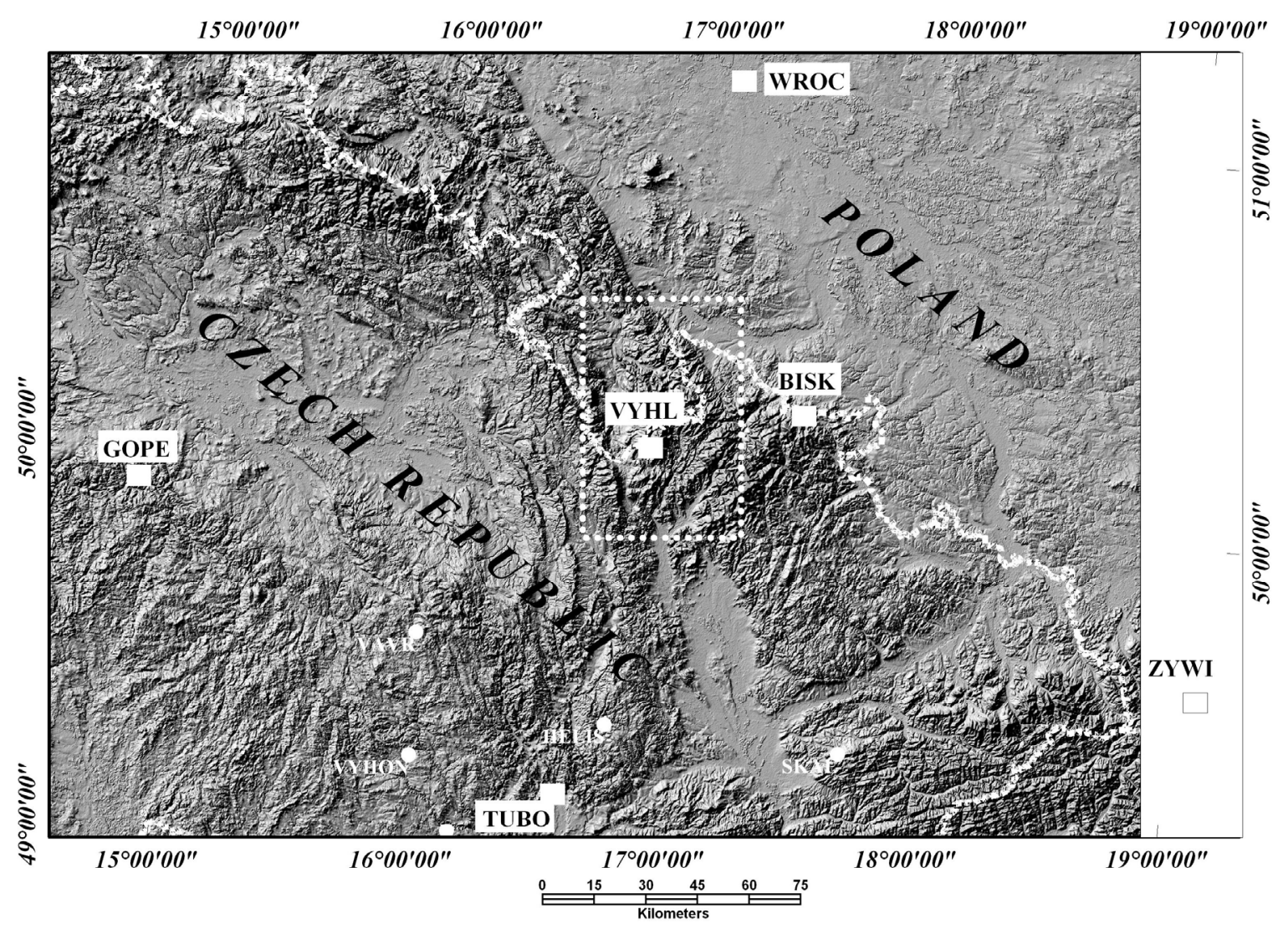

Fig. 1 Localization of the area of Králický Sněžník massif at the SRTM2 map (NASA/USGS 2006).

Table 1 Overview of observations realized in Local Geodynamic Sněžník Network.

\begin{tabular}{|c|c|c|c|c|}
\hline Year & $\begin{array}{l}\text { Duration of } \\
\text { obsevations }\end{array}$ & Day of year & $\begin{array}{c}\text { Number of } \\
\text { measured points }\end{array}$ & $\begin{array}{l}\text { Number of different } \\
\text { antenna types }\end{array}$ \\
\hline 1992 & \multicolumn{4}{|c|}{ Too short observations } \\
\hline 1993 & \multicolumn{4}{|c|}{ Too short observations } \\
\hline 1994 & $1-3 \mathrm{~h}$ & 141 a 142 & 13 & 1 \\
\hline 1995 & \multicolumn{4}{|c|}{ Too short observations } \\
\hline 1996 & $1-3 \mathrm{~h}$ & $137-140$ a $254-257$ & 14 & 3 \\
\hline 1997 & $6 \mathrm{~h}$ & $\begin{array}{c}125-138,241-243 \\
265-268\end{array}$ & 7 & 1 \\
\hline 1998 & $6 \mathrm{~h}$ & $129-137,261-264$ & 9 & 5 \\
\hline 1999 & $24 \mathrm{~h}$ & $139-142$ & 4 & 1 \\
\hline 2000 & $24 \mathrm{~h}$ & $125-134$ & 13 & 4 \\
\hline 2001 & $12 \mathrm{~h}$ & $126-133$ & 14 & 4 \\
\hline 2002 & $24 \mathrm{~h}$ & $129-139$ & 11 & 3 \\
\hline 2003 & $24 \mathrm{~h}$ & $136-138$ & 14 & 4 \\
\hline 2004 & $24 \mathrm{~h}$ & $129-137$ & 11 & 4 \\
\hline 2005 & $24 \mathrm{~h}$ & $133-141$ & 14 & 4 \\
\hline 2006 & $24 \mathrm{~h}$ & $127-133$ & 12 & 3 \\
\hline 2007 & $24 \mathrm{~h}$ & $133-140$ & 12 & 4 \\
\hline 2008 & $24 \mathrm{~h}$ & $128-135$ & 9 & 4 \\
\hline 2009 & $24 \mathrm{~h}$ & $133-143$ & 13 & 4 \\
\hline 2010 & $24 \mathrm{~h}$ & $136-143$ & 12 & 4 \\
\hline 2011 & $24 \mathrm{~h}$ & $126-135$ & 11 & 4 \\
\hline
\end{tabular}


reprocessing using the IGS reprocessed products related to only one reference frame and to the absolute model of antenna phase center variation is very promising.

\section{USED PROCESSING METHODS AND THEIR RESULTS}

Determination of spatial coordinates using GNSS measurements can be done using two different approaches. First is the absolute method of Precise Point Positioning (PPP) which is on the one hand highly dependent on the quality of inputs (both measured data and supporting products) but on the other hand the estimation of point velocities is independent from velocities on reference points because the coordinates are determined directly from the measurements in the reference frame of satellite orbits. The second method is the widely used relative method, using which the coordinates and velocities are determinate relatively to the chosen reference points. During the comprehensive reprocessing of GNSS measurement form LGSN both absolute and relative approach were used. All the data were processed in Bernese GPS software version 5.0 (BSW5), which allows the highest control over the processing including adoption of IGS products.

\section{PPP METHOD}

For the whole data set the daily solutions were computed using standard Bernese processing engine (BPE) script for PPP adopted for data from LGSN. Subsequently the daily solutions were combined using ADDNEQ2. The results are the coordinates and velocities in given epoch and reference frame. Because for most of the time span the IGS products were related to the IGS05, was the IGS05 used as a final reference frame. For the evaluation of possible geodynamic movements were the estimated velocities compared with two most common models, the geological No Net Rotation - Northwestern University VELocity model 1A (NNR-NUVEL-1A) introduced in (DeMets, 1994) and a plate motion and deformation model of Actual Plate Kinematic Model - version 2005 (APKIM2005) presented by (Drewes, 2009). Velocities of LGSN points in both models were calculated using University NAVSTAR Consortium (UNAVCO) web service of Tectonic Plate Motion Calculator (2008). Residual velocities were computed by subtracting the velocities in both models from velocities of the PPP method. The resulting residual velocities are shown in Figure 2. It is worth to mention the well correspondence of residual velocities related to the NNR-NUVEL-1A model for example with the results presented in (Bogusz et al., 2012, p. 76) from processing of ASGEUPOS which points are close to the area of LGSN. But it is also clearly visible, that there is a difference between the resulting residual velocities in relation to both models. This phenomenon is caused by different velocity of IGS05 reference frame in relation to the both used models. For estimation of the relative velocity between the reference frame of IGS05 and both models, the velocities of four closest IGS core stations given in IGS05 were compared to its velocities computed using the Tectonic Plate Motion Calculator of UNAVCO. The average difference between the IGS05 and NNR-NUVEL-1A was detected on the level of $2 \mathrm{~mm} /$ year in north direction and $0.6 \mathrm{~mm} /$ year in east direction and between the IGS05 and APKIM2005 is the average difference $-1 \mathrm{~mm} /$ year in north direction and $0.5 \mathrm{~mm} /$ year for east direction.

After a removal of those differences the residual velocities in relation to the both agree on the level of $0.1 \mathrm{~mm} /$ year for north direction and $0.2 \mathrm{~mm} /$ year for east direction. The final residual velocities are listed in Table 2. Although the results gained from absolute method are quite impressive, it is better to use the relative method for the final evaluation because of the better elimination of the systematic errors. For information the average RMSE (Root Mean Square Error) of coordinates taken from comparison of daily solutions (repeatability of coordinates) is $6 \mathrm{~mm}$ in northing and $9 \mathrm{~mm}$ in easting as listed in Table 3 . The height component of coordinates was not evaluated.

\section{RELATIVE METHOD}

When using relative method, the coordinates and velocities of LGSN points were determined in relation to the closest IGS points Figure 3). Because of the wide time span, only few points were able to fulfill all the criteria (availability of observation data, contribution on reference frame realization and stability) for reference points so only four IGS core stations were chosen, namely BOR1, JOZE, POTS and WTZR. The processing was done using modified script of Bernese processing engine RNX2SNX. The modification stemmed besides to adaption to the LGSN data and reprocessed IGS products from use of STAR strategy for baseline creation, so that all baselines from central point VYHL were computed. Rest of the settings was kept unchanged. Initially all the daily solutions were resolved and subsequently combined using ADDNEQ2. The overall results are the coordinates and velocities in desired epoch in IGS05 reference frame. To evaluate the possible geodynamic movements, again the comparison with NNR-NUVEL-1A and APKIM2005 models was realized (Figure 3 ). The final residual velocities after subtraction of geologic model velocities and relative velocity between each model and used reference frame are listed in Table 4 while the resulting coordinates in IGS05 reference frame with their accuracies are listed in Table 5.

At first sight is visible that the residual velocities are in absolute value below $1 \mathrm{~mm} /$ year besides for points VLAS and KAZA. But the higher residual velocities for points KAZA and VLAS are probably caused by higher variance of each coordinate component in their time series. 
Table 2 Residual velocities of PPP method after subtraction of geological model of NNR-NUVEL-1A, plate motion model of APKIM2005 and residual velocity of used reference frame.

\begin{tabular}{|c|c|c|c|c|c|}
\hline \multicolumn{3}{|c|}{ Northing } & \multicolumn{3}{|c|}{ Easting } \\
\hline $\begin{array}{c}\text { NNR-NUVEL- } \\
-1 \mathrm{~A}\end{array}$ & APKIM2005 & $\begin{array}{l}\text { RMSE of N } \\
\text { velocity from } \\
\text { BSW5 } \\
\end{array}$ & $\begin{array}{c}\text { NNR-NUVEL- } \\
-1 \mathrm{~A}\end{array}$ & APKIM2005 & $\begin{array}{l}\text { RMSE of E velocity } \\
\text { from BSW5 }\end{array}$ \\
\hline 0.5 & 0.4 & 0.1 & -2.0 & -2.1 & 0.2 \\
\hline 0.2 & 0.1 & 0.2 & -0.3 & -0.4 & 0.3 \\
\hline-0.2 & -0.3 & 0.1 & -1.7 & -1.8 & 0.1 \\
\hline-1.1 & -1.2 & 0.2 & -1.3 & -1.4 & 0.2 \\
\hline-2.2 & -2.3 & 0.1 & -2.8 & -2.9 & 0.2 \\
\hline 1.1 & 1.0 & 0.2 & -1.5 & -1.6 & 0.3 \\
\hline-0.2 & -0.3 & 0.1 & -1.0 & -1.1 & 0.1 \\
\hline-0.6 & -0.7 & 0.1 & -0.7 & -0.8 & 0.1 \\
\hline-0.1 & -0.2 & 0.1 & -1.0 & -1.1 & 0.1 \\
\hline 0.4 & 0.3 & 0.1 & 0.5 & 0.4 & 0.2 \\
\hline-0.3 & -0.4 & 0.1 & -1.2 & -1.3 & 0.2 \\
\hline 0.8 & 0.7 & 0.1 & -2.2 & -2.3 & 0.2 \\
\hline 0.9 & 0.8 & 0.1 & -0.3 & -0.5 & 0.1 \\
\hline 0.5 & 0.4 & 0 & -1.3 & -1.4 & 0.1 \\
\hline
\end{tabular}

Table 3 Coordinates and velocities gained using PPP method with their accuracy. (RMSE mean root mean square error of coordinates, $\mathrm{RN}$ and $\mathrm{RE}$ are the variances (repeatability) taken from comparison of individual solution from whole tome span, $\mathrm{VN}$ and $\mathrm{VE}$ are velocities in northing or easting respectively).

\begin{tabular}{ccccccccc}
\hline Point & Northing & $\begin{array}{c}\text { RMSE N } \\
{[\mathrm{mm}]}\end{array}$ & $\begin{array}{c}\text { RN } \\
{[\mathrm{mm}]}\end{array}$ & Easting & $\begin{array}{c}\text { RMSE E } \\
{[\mathrm{mm}]}\end{array}$ & $\begin{array}{c}\text { RE } \\
{[\mathrm{mm}]}\end{array}$ & $\begin{array}{c}\text { VN } \\
{[\mathrm{mm} / \mathrm{r}]}\end{array}$ & $\begin{array}{c}\text { VE } \\
{[\mathrm{mm} / \mathrm{r}]}\end{array}$ \\
\hline DMOR & $50^{\circ} 7^{\prime} 46.04088^{\prime \prime}$ & 0.3 & 6.9 & $16^{\circ} 48^{\prime} 0.359222^{\prime \prime}$ & 0.4 & 9.0 & 15.3 & 18.3 \\
KAZA & $50^{\circ} 11^{\prime} 22.84562^{\prime \prime}$ & 0.8 & 4.9 & $16^{\circ} 50^{\prime} 18.058291^{\prime \prime}$ & 1.3 & 25.5 & 15.0 & 20.0 \\
KLEP & $50^{\circ} 9^{\prime} 15.21663^{\prime \prime}$ & 0.3 & 4.0 & $16^{\circ} 47^{\prime} 15.778657^{\prime \prime}$ & 0.5 & 5.9 & 14.6 & 18.6 \\
LOMA & $50^{\circ} 6^{\prime} 58.37788^{\prime \prime}$ & 0.7 & 8.8 & $16^{\circ} 47^{\prime} 18.259477^{\prime \prime}$ & 0.9 & 7.9 & 13.7 & 19.0 \\
MALI & $50^{\circ} 7^{\prime} 16.99773^{\prime \prime}$ & 0.4 & 11.3 & $16^{\circ} 48^{\prime} 55.205008^{\prime \prime}$ & 0.7 & 11.0 & 12.6 & 17.5 \\
PRSO & $50^{\circ} 8^{\prime} 45.89299^{\prime \prime}$ & 0.9 & 5.7 & $16^{\circ} 47^{\prime} 22.860957^{\prime \prime}$ & 1.3 & 4.8 & 15.9 & 18.8 \\
SCZE & $50^{\circ} 12^{\prime} 25.29714^{\prime \prime}$ & 0.4 & 5.2 & $16^{\circ} 50^{\prime} 50.857188^{\prime \prime}$ & 0.6 & 5.6 & 14.6 & 19.3 \\
STHR & $50^{\circ} 11^{\prime} 37.89790^{\prime \prime}$ & 0.4 & 4.4 & $16^{\circ} 51^{\prime} 48.730654^{\prime \prime}$ & 0.6 & 7.0 & 14.2 & 19.6 \\
SUSI & $50^{\circ} 10^{\prime} 25.92042^{\prime \prime}$ & 0.4 & 4.5 & $16^{\circ} 51^{\prime} 47.812231^{\prime \prime}$ & 0.6 & 7.9 & 14.7 & 19.3 \\
TARA & $50^{\circ} 8^{\prime} 16.59092^{\prime \prime}$ & 0.7 & 4.8 & $16^{\circ} 48^{\prime} 21.234901^{\prime \prime}$ & 1.2 & 9.4 & 15.2 & 20.8 \\
TVDR & $50^{\circ} 10^{\prime} 46.79378^{\prime \prime}$ & 0.4 & 7.9 & $16^{\circ} 49^{\prime} 44.623435^{\prime \prime}$ & 0.5 & 12.6 & 14.5 & 19.1 \\
VESE & $50^{\circ} 5^{\prime} 41.75846^{\prime \prime}$ & 0.2 & 5.9 & $16^{\circ} 47^{\prime} 17.932757^{\prime \prime}$ & 0.4 & 6.4 & 15.6 & 18.1 \\
VLAS & $50^{\circ} 5^{\prime} 17.79710^{\prime \prime}$ & 0.3 & 8.2 & $16^{\circ} 53^{\prime} 38.620189^{\prime \prime}$ & 0.4 & 9.5 & 15.7 & 20.0 \\
& $50^{\circ} 8^{\prime} 42.55077^{\prime \prime}$ & 0.2 & 3.9 & $16^{\circ} 49^{\prime} 27.171100^{\prime \prime}$ & 0.3 & 6.2 & 15.3 & 19.0 \\
\hline
\end{tabular}


Table 4 Residual velocities computed with the relative method after subtraction of geological model of NNRNUVEL-1A, plate motion model of APKIM2005 and residual velocity of used. reference frame.

\begin{tabular}{|c|c|c|c|c|c|c|}
\hline \multirow[b]{3}{*}{ POINT } & \multicolumn{6}{|c|}{$\begin{array}{l}\text { Residual velocities after subtraction of both models and residual velocity of used reference frame } \\
{[\mathrm{mm} / \mathrm{year}]}\end{array}$} \\
\hline & \multicolumn{3}{|c|}{ Northing } & \multicolumn{3}{|c|}{ Easting } \\
\hline & $\begin{array}{c}\text { NNR-NUVEL } \\
-1 \mathrm{~A}\end{array}$ & APKIM2005 & $\begin{array}{l}\text { RMSE of N velocity } \\
\text { from BSW5 }\end{array}$ & $\begin{array}{c}\text { NNR- } \\
\text { NUVEL -1A }\end{array}$ & APKIM2005 & $\begin{array}{c}\text { RMSE of E } \\
\text { velocity from } \\
\text { BSW5 } \\
\end{array}$ \\
\hline DMOR & 0.2 & 0.1 & 0.1 & 0.3 & 0.2 & 0.1 \\
\hline KAZA & -0.6 & -0.7 & 0.1 & 1.5 & 1.4 & 0.1 \\
\hline KLEP & -0.1 & -0.2 & 0 & -0.3 & -0.4 & 0 \\
\hline LOMA & 0.1 & 0.0 & 0.1 & 0.6 & 0.5 & 0.1 \\
\hline MALI & -0.7 & -0.8 & 0.1 & -0.1 & -0.2 & 0.1 \\
\hline PRSO & 0.7 & 0.6 & 0.1 & 0.6 & 0.5 & 0.1 \\
\hline SCZE & -0.1 & -0.2 & 0 & 0.1 & 0.0 & 0 \\
\hline STHR & -0.6 & -0.7 & 0 & -0.1 & -0.2 & 0 \\
\hline SUSI & 0.1 & 0.0 & 0 & 0.4 & 0.3 & 0 \\
\hline TARA & -0.3 & -0.4 & 0.1 & 0.6 & 0.5 & 0.1 \\
\hline TVDR & -0.6 & -0.7 & 0.1 & 0.4 & 0.3 & 0.1 \\
\hline VESE & 0.5 & 0.4 & 0.1 & -0.2 & -0.3 & 0 \\
\hline VLAS & 1.2 & 1.1 & 0 & 0.5 & 0.3 & 0 \\
\hline VYHL & 0.5 & 0.4 & 0 & 0.1 & 0.0 & 0 \\
\hline
\end{tabular}

Table 5 Coordinates and velocities (IGS05) gained using relative method with their accuracy. (RMSE - root mean square error of coordinates, RN and RE are the variances (repeatability) taken from comparison of individual solution from whole tome span, $\mathrm{VN}$ and $\mathrm{VE}$ are velocities in northing or easting respectively).

\begin{tabular}{ccccccccc}
\hline Point & Northing & $\begin{array}{c}\text { RMSE N } \\
{[\mathrm{mm}]}\end{array}$ & $\begin{array}{c}\text { RN } \\
{[\mathrm{mm}]}\end{array}$ & Easting & $\begin{array}{c}\text { RMSE E } \\
{[\mathrm{mm}]}\end{array}$ & $\begin{array}{c}\text { RE } \\
{[\mathrm{mm}]}\end{array}$ & $\begin{array}{c}\text { VN } \\
{[\mathrm{mm} / \mathrm{r}]}\end{array}$ & $\begin{array}{c}\text { VE } \\
{[\mathrm{mm} / \mathrm{r}]}\end{array}$ \\
\hline DMOR & $50^{\circ} 7^{\prime} 46.040956^{\prime \prime}$ & 0.3 & 6.4 & $16^{\circ} 48^{\prime} 0.358332^{\prime \prime}$ & 0.2 & 2.7 & 15.0 & 20.6 \\
KAZA & $50^{\circ} 11^{\prime} 22.845793^{\prime \prime}$ & 0.9 & 4.0 & $16^{\circ} 50^{\prime} 18.057484^{\prime \prime}$ & 0.7 & 6.1 & 14.2 & 21.8 \\
KLEP & $50^{\circ} 9^{\prime} 15.216585^{\prime \prime}$ & 0.3 & 2.1 & $16^{\circ} 47^{\prime} 15.777583^{\prime \prime}$ & 0.2 & 2.4 & 14.7 & 20.0 \\
LOMA & $50^{\circ} 6^{\prime} 58.377753^{\prime \prime}$ & 0.5 & 5.0 & $16^{\circ} 47^{\prime} 18.258577^{\prime \prime}$ & 0.3 & 2.3 & 14.9 & 20.9 \\
MALI & $50^{\circ} 7^{\prime} 16.997497^{\prime \prime}$ & 0.4 & 6.2 & $16^{\circ} 48^{\prime} 55.204005^{\prime \prime}$ & 0.3 & 5.0 & 14.1 & 20.2 \\
PRSO & $50^{\circ} 8^{\prime} 45.8931^{\prime \prime}$ & 0.7 & 1.3 & $16^{\circ} 47^{\prime} 22.859641^{\prime \prime}$ & 0.5 & 1.1 & 15.5 & 20.9 \\
SCZE & $50^{\circ} 12^{\prime} 25.297148^{\prime \prime}$ & 0.3 & 3.1 & $16^{\circ} 50^{\prime} 50.85648^{\prime \prime}$ & 0.2 & 3.1 & 14.7 & 20.4 \\
STHR & $50^{\circ} 11^{\prime} 37.897838^{\prime \prime}$ & 0.3 & 3.7 & $16^{\circ} 51^{\prime} 48.730026^{\prime \prime}$ & 0.3 & 6.3 & 14.2 & 20.2 \\
SUSI & $50^{\circ} 10^{\prime} 25.920371^{\prime \prime}$ & 0.4 & 3.0 & $16^{\circ} 51^{\prime} 47.81151^{\prime \prime}$ & 0.3 & 3.7 & 14.9 & 20.7 \\
TARA & $50^{\circ} 8^{\prime} 16.591097^{\prime \prime}$ & 1.1 & 4.6 & $16^{\circ} 48^{\prime} 21.234701^{\prime \prime}$ & 0.7 & 3.3 & 14.5 & 20.9 \\
TVDR & $50^{\circ} 10^{\prime} 46.793863^{\prime \prime}$ & 0.3 & 4.1 & $16^{\circ} 49^{\prime} 44.622308^{\prime \prime}$ & 0.3 & 3.3 & 14.2 & 20.7 \\
VESE & $50^{\circ} 5^{\prime} 41.758497^{\prime \prime}$ & 0.2 & 4.5 & $16^{\circ} 47^{\prime} 17.932141^{\prime \prime}$ & 0.2 & 3.9 & 15.3 & 20.1 \\
VLAS & $50^{\circ} 5^{\prime} 17.797104^{\prime \prime}$ & 0.3 & 4.1 & $16^{\circ} 53^{\prime} 38.619439^{\prime \prime}$ & 0.2 & 3.0 & 16.0 & 20.8 \\
VYHL & $50^{\circ} 8^{\prime} 42.550775^{\prime \prime}$ & 0.2 & 2.8 & $16^{\circ} 49^{\prime} 27.170334^{\prime \prime}$ & 0.2 & 2.7 & 15.3 & 20.4 \\
\hline
\end{tabular}

\section{CONCLUSION}

Comprehensive reprocessing of GNSS data measured in Local Geodynamic Sněžník network over period of 15 years using the highest quality products of first IGS reprocessing has brought further factual results to the discussion about the character of movement tendencies in the region. For the first time the absolute method of precise point positioning was 
used within the LGSN and thanks to the quality of used IGS products provided interesting results unaffected by the relations to the reference points. However the accuracy of the PPP method is even when using IGS reprocessed products not sufficient for evaluation of geodynamic tendencies in the area of interest. Better overview of potential crustal movements in the area of Králický Sněžník massif was provided by the more common relative method of GNSS processing. According to its results the area of interest seems to be in good accordance with both compared models (NNR-NUVEL-1A and APKIM2005). Resulting residual velocities of LGSN points are despite relatively frequent seismotectonic activities (Špaček et al., 2006) below $1 \mathrm{~mm} /$ year for most of the points. Only for two points (KAZA and VLAS) the residual velocities are higher than $1 \mathrm{~mm} /$ year bur are most probably caused by higher variance of each coordinate components in its time series. Although the most accurate inputs in form of IGS reprocessed products were used and whole reprocessing was oriented to obtain the final results of highest accuracy, there are still many systematic errors which influent the overall results. Among the others the influence of variations of phase centers for used antennas, near-field multipath or the effect of ionosphere and troposphere should be named as the main sources of remaining systematic errors.

\section{ACKNOWLEDGEMENT}

The research was supported by the EU project CZ 1.05/2.1.00/03.0097 within the regional centre "AdMaS", and with support of the project MSM 0021630519.

We would like to thank all students of the Institute of Geodesy, who participated in the field education process in Dolní Morava area, for help and support with providing GNSS measurements at the points of the Kralický Sněžník network.

\section{REFERENCES:}

Birkenmayer, K., Péckay, Z., Grabowski, J., Lorenc, M.W. and Zagożdżon, P.P.: 2002, Radiometric dating of the Tertiary volcanics in Lower Silesia, Poland. II. K-Ar and Paleomagnetic data from Neogene basanites near Lądek Zdrój, Sudetes Mts. Annales Societatis Gologorum Poloniae, 72, 119-129.

Bogusz, J., Figurski, M., Kontny, B. and Grzempowski, P.: 2012, Unmodelled effects in the horizontal velocity field determination: ASG-EUPOS case study. Artificial Satellites. 2012-1-1, 47, No. 2, 67-79. DOI: $10.2478 / \mathrm{v} 10018-012-0014-\mathrm{x}$

Cacoń, S., Švábenský, O., Kontny, B., Weigel, J., Jamroz, O., Ćmielewski, K., Bosy, J., Kaplon, J. and Machotka, R.: 2004, Deformation analysis of the upper part of the Earth crust in the Snieznik Massif (Polish and Czech sides between 1993 and 2003), Acta Geodyn. Geomater. 1, No. 3 (135), 59-67.

Cacoń, S., Weigel, J., Švábenský, O., Kontny, B. and Jamroz, O.: 1996, Geodynamic structure of the Massif of Śnieżnik (in Polish), In: Jahn, A., Kozlowski, S. and Pulina, M. (Eds.): The Massif of Śnieżnik Changes in natural environment, Polish Ecological Agency Publ., Warszaw, 57-70.

DeMets, C. et al.: 1994, Effect of recent revisions to the geomagnetic reversal time scale on estimates of current plate motions, Geophysical Research Letters., 21, 20, 2191-2194. DOI: 10.1029/94GL02118

Drewes, H.: 2009, The actual plate kinematic and crustal deformation model APKIM2005 as basis for a nonRotating ITRF, International Association of Geodesy symposia. No. 134, 95-99. DOI: $10.1007 / 978-3-642-00860-3 \quad 15$

Ferland, R.: 2010, IGS Repro1 Combined Products SINEX, orbit and (preliminary) clock products. 26. April 2010.<Remi.Ferland @ NRCan-RNCan.gc.ca> [cit. 2013-01-31]. Available from: http://igscb.jpl.nasa.gov/mail/igsmail/2010/msg00084. html.

Gawlikowska, E. and Opletal, M.:1997, Snieznik area. Geological map for tourists. Český geologický ústav Praha, Panstwowy Instytut Geologiczny Warszawa.

Jamrosz, O.: 2008, Geodynamical investigations in the local network Snieznik Klodzki. Acta Geodyn. Geomater., 5, No. 3 (151), 323-328.

IGS Products :2009, [online]., 17.06.2009 [cit. 2013-01-31]. IGS Products. Available from: http://igscb.jpl.nasa.gov/components/prods.html

Mahel, M.: 1973, Tectonic map of the Carpathian- Balkan mountain system and adjacent areas. Published by Geological Institute in BratislavalUNESCO, Paris 1973.

Meindl, M., Dach R. and Jean, Y.: 2012, Technical report 2011: International GNSS service [online]. 2012, 248 s. Available from: ftp://igs.org/pub/resource/pubs/2011_techreport.pdf.

SRTM (Shuttle Radar Topography Mission) DEM (Digital Elevation Model), NASA/USGS, 2006.

Steigenberger, P., Romero, I. and Fang, P.: 2006, Reprocessing Issues, Standardization, New models [online]. Darmstadt, 2006 [cit. 2012-02-24]. Available from: http://nng.esoc.esa.de/ws2006/REPR1.pdf

Špaček, P., Sýkorová, Z., Pazdírková, J., Švancara, J. and Haviŕ, J.: 2006, Present-day seismicity of the SouthEastern Elbe fault system (NE Bohemia Massif), Stud. Geophys. Geod., 50, 233-258. DOI: $10.1007 / \mathrm{s} 11200-006-0014-\mathrm{z}$

Švábenský, O. and Weigel, J.: 1999, Local geodynamic network "Sněžník", Exploration Geophysics, Remote Sensing and Environment VI.2, 4-7.

Švábenský, O. and Weigel, J.: 2005, Impact of some site dependent factors on GPS displacement monitoring. Acta Geodyn. Geomater., 2, No. 3 (139), 43-47.

Švábenský, O. and Weigel, J.: 2007, Long-term positional monitoring of station VYHL of the Sněžník network. Acta Geodyn. Geomater., 4, No. 4, 201-206.

Švábenský, O., Weigel, J. and Pospíšil, L.: 2012, Geodynamic network Sněžník: Reprocessing and analyzes of satellite data in czech part over the period 1997-2011. Acta Geodyn. Geomater, 9, No. 3.(167), 339-347.

Tectonic Plate Motion Calculator from UNAVCO.: 2008 [online]. [cit. 2013-01-31]. Science Product Support Plate Motion Calculator. Available from: http://sps.unavco.org/crustal_motion/dxdt/nnrcalc/. 